\title{
Analyzing the Role of Creative Industries in National Economy of Japan: 1995-2005
}

\author{
Ubaidillah Zuhdi 1 ,2 \\ ${ }^{1}$ Department of Industrial Administration, Tokyo University of Science, Noda, Japan \\ ${ }^{2}$ School of Business and Management, Institut Teknologi Bandung, Bandung, Indonesia \\ Email: ubaidillah.zuhdi@gmail.com
}

Received 1 February 2014; revised 5 March 2014; accepted 12 March 2014

Copyright (C 2014 by author and Scientific Research Publishing Inc.

This work is licensed under the Creative Commons Attribution International License (CC BY).

http://creativecommons.org/licenses/by/4.0/

(c) (i) Open Access

\begin{abstract}
The purposes of this study are 1) to get another perspective related to the role of creative industries in national economy of Japan from 1995-2005 and 2) to know the ways to improve these sectors. This study employs Input-Output (IO) analysis as a tool of analysis. More specifically, this study uses simple output multipliers and demand-pull IO quantity model. Comparison with previous study is conducted in order to achieve the first objective. Another perspective related to above role is obtained from this study, namely creative industries, using simple output multipliers method, did not have an important role in national economy of Japan in analysis period. The results also show that the patterns of total output of creative industries of Japan on future period are not identic. Nevertheless, these sectors have one similarity, namely the modification of import will decrease their total output. This phenomenon indicates that import restriction related to these sector's products is needed.
\end{abstract}

\section{Keywords}

Creative Industries; Perspective; Input-Output Analysis; Import Restriction; Japan

\section{Introduction}

Nowadays, the contribution of creative industries could be perceived globally. This phenomenon clearly described by [1]:

"Globally, creative industries are estimated to account for more than 7 per cent of the world's gross domestic product and are forecast to grow, on average, by 10 per cent a year. While the economic and employment-generating potential of these industries is vast and many developing and transition countries have great potential in this area, most are still marginal players, despite their rich cultural heritage and an inexhaustible pool of 
talent. That position reflects a combination of domestic policy weakness and global systemic biases. Ongoing research by the UNCTAD secretariat has emphasized the potential of these industries in developing countries."

The contribution of above industries is also perceived in macro level. Reference [2] explained this condition:

"The creative industries are a significant contributor to the UK economy-accounting for $7.9 \%$ of GDP, and growing significantly faster than the economy as a whole."

Above facts indicate that creative industries are important components in society.

There are many previous studies discussing about creative industries. For example, [3] investigated the contribution of creative industries in urban economies of cities of Global South. Reference [4] examined the contribution of creative industries to the economic activity of Japan from macroscopic view while [5] investigated the case of Indonesia. These studies employed Structural Decomposition Analysis (SDA) as a tool of analysis. Besides, [6] analyzed the dynamics of total outputs of creative industries of Japan using Input-Output (IO) analysis. However, study compares the results of previous study, which the topic of discussion is the role of creative industries in national economy of specific country, is still thin. The kind of study is important because it can describe more detail about this role. This study is conducted to fulfill this gap.

The purpose of this study is to get another perspective related to the role of creative industries in national economy. This study will focus on Japan. Besides, this study also tries to know the ways to improve these sectors. The period of analysis of this study is from 1995-2005. This study employs IO analysis in order to achieve the objectives. The structure of this study is described as follows. Section 2 reviews the literatures used in this study. The methodology of this study will be explored in Section 3. Section 4 elaborates the calculation results and analysis of these results. Section 5 gives the conclusions and suggests the further researches.

\section{Literature Review}

\subsection{Creative Industry Definition}

According to [7], the definition of creative industries is:

"Those industries which have their origin in individual creativity, skill and talent and which have a potential for wealth and job creation through the generation and exploitation of intellectual property."

\subsection{Creative Industries in Japan}

The condition of creative industries in Japan was described by [8] as follows:

“According to the 2006 Establishment and Enterprise Census, Japan's creative industries comprised 250,000 establishments and 2.19 million employees, representing $4.4 \%$ and $4.0 \%$ respectively of all industries... By number of establishments, the sector of (3) crafts, art, antiques and traditional culture boasts the largest size, comprising $24.8 \%$ of Japan's creative industries... Creative industries are most concentrated in the Tokyo 23-ku, which accounts for $17.1 \%$ of Japan's creative establishments and $35.0 \%$ of creative employees. Moreover, as a share of local industry, Tokyo's creative industries also lead the nation with a 7.8\% share of all local establishments and $11.2 \%$ share of all local employees."

\section{Methodology}

As mentioned in introduction, the objectives of this study are 1) to get another perspective related to the role of creative industries in national economy of Japan and 2) to know the ways to improve these sectors. The period of analysis of this study is from 1995-2005. This study employs IO analysis as a tool of analysis. More specifically, this study uses simple output multipliers and demand-pull IO quantity model. IO tables of Japan for 1995, 2000, and 2005 are used as data.

Methodology of this study is described as follows. First, the aggregation process is conducted for the data. The number of Japanese industrial sectors for 1995, 2000, and 2005 was 93, 104, and 108, respectively. These sectors are reclassified into 89 sectors. The aim of this process is to get the compatibility among different periods. A detailed description of these sectors is given in an appendix.

Second, I select creative industries of Japan from aggregated sectors. This selection is based on the classification which is made by [8]. Table 1 shows these industries. The next step is to explore the previous study which 
Table 1. Japanese creative industries used in this study.

\begin{tabular}{ccc}
\hline No. & Sector Number & Sector Name \\
\hline 1 & 19 & Printing, plate making and book binding \\
2 & 47 & Electrical appliance \\
3 & 52 & Miscellaneous manufacturing products \\
4 & 76 & Goods rental and leasing services \\
5 & 81 & Amusement and recreational services \\
6 & 84 & Other personal services \\
7 & 87 & \\
\hline
\end{tabular}

(Source: [4]).

is conducted by [4]. This step is needed in achieving the first objective of this study. They analyzed the role of creative industries in economic activities of Japan from 1995-2005 using SDA, one of analysis tool in IO analysis. Their study is chosen as compared study because it has similar topic and methodology as well as the creative industries used.

The fourth step is to do the calculation using simple output multipliers method. This method is chosen because it can analyze the total production value of all sectors in economy which is needed in satisfying a monetary unit's worth of final demand for output of specific sector [9]. In other words, this method can analyze the effect of increase of one unit in particular sectors' final demand on national economy, the total production made by all industrial sectors in economy in order to fulfill the escalation. According to [9], the following equation is applied in the simple output multipliers calculation:

$$
m(o)_{j}=\sum_{i=1}^{n} l_{i j}
$$

where $m(o)_{j}$, $n$, and $l_{i j}$ are simple output multiplier for sector $j$, the numbers of sectors, and sector-to-sector multipliers matrix, respectively.

The next step is to conduct the analysis related to the efforts in improving the Japanese creative industries. The demand-pull IO quantity model is employed in this step. Reference [9] described this model using the following equation:

$$
x^{1}=L^{0} f^{1}
$$

where $x, L$, and $f$ are matrices of total output of sectors, Leontief inverse, and final demand of sectors, respectively. 0 and 1 indicate initial and future times, respectively. Initial period in this calculation is 2005. The scenarios of final demand modification used in this study are described in Table 2.

In this study, "pure change" condition is considered in the calculation using Equation (2). This condition describes the situation which modifications of final demand are only addressed to Japanese creative industries. Recommendations are suggested based on the calculation results. Conclusions of this study and suggestions for further research are described on final step.

\section{Results and Analysis}

\subsection{The Results of Previous Study}

Tables 3 and 4 describe the results of previous study, namely the top five sectors influencing structural changes in the national economy of Japan from 1995-2000 and 2000-2005, respectively. More specifically, these tables show the results of calculation of Japanese industrial sector's gross output changes from 1995 through 2005 using SDA. Similar to this study, IO tables of Japan for 1995, 2000, and 2005 were used in the calculation. Based on information in the tables, one of the creative industries includes in former table while opposite phenomenon is seen in latter one. In other words, creative industries had an important role in national economy of Japan in 1995-2000 while the importance of these industries could not be observed in 2000-2005. 
Table 2. The scenarios of final demand modification used in this study.

\begin{tabular}{cccc}
\hline & \multicolumn{3}{c}{ Scenario } \\
\cline { 2 - 4 } Component of final demand & 1 & 2 & 3 \\
\cline { 2 - 4 } & Export modification & Import modification & $\begin{array}{c}\text { Outside households } \\
\text { consumption modification }\end{array}$ \\
\cline { 2 - 4 } Export & Rises 30\% & Constant & Constant \\
Import & Constant & Rises 30\% & Constant \\
Outside households consumption & Constant & Constant & Rises 30\% \\
\hline
\end{tabular}

(Source: [6]).

Table 3. Top five sectors influencing structural changes in the Japanese national economy, 1995-2000.

\begin{tabular}{cccc}
\hline No. & Sector Number & Sector Name & Value (100 Million Yen) \\
\hline 1 & 74 & Public administration & 100235.87 \\
2 & 80 & Advertising, survey and information services & 97726.61 \\
3 & 77 & Medical service and health & 80261.19 \\
4 & 72 & Communication & 70072.69 \\
5 & 47 & Electrical appliance & 37315.73 \\
\hline
\end{tabular}

(Source: [4]).

Table 4. Top five sectors influencing structural changes in the Japanese national economy, 2000-2005.

\begin{tabular}{cccc}
\hline No. & Sector Number & Sector Name & Value (100 Million Yen) \\
\hline 1 & 73 & Broadcasting and information services & 267081.42 \\
2 & 60 & Commerce & 112557.90 \\
3 & 48 & Motor vehicles & 103839.35 \\
4 & 37 & Steel products & 53697.28 \\
5 & 77 & Medical service and health & 50620.37 \\
\hline
\end{tabular}

(Source: [4]).

\subsection{The Calculation Using Simple Output Multipliers Method}

Figures 1-3 describe the results of calculation using simple output multipliers method for Japanese industrial sectors in 1995, 2000, and 2005, respectively. On the other hand, Tables 5-7 explain the top five Japanese industrial sectors viewed from simple output multipliers in these years. Creative industries do not appear in these tables. In other words, from the point of view of this method, these industries did not have an important role in the Japanese national economy in 1995-2005.

Table 8 shows the changes and patterns of simple output multipliers of Japanese creative industries in 19952005. Three patterns appear on these sectors, namely 1) increasing-decreasing, 2) increasing, and 3) decreasingincreasing. The dominant pattern is a second one. Based on this fact, I argue that the role of these industries in national economy of Japan was more important in 2005 than 1995.

Previous comparison show that the role of creative industries in Japanese national economy from 1995-2005 could be different if another method is used in analysis. This difference appears might be caused by the nature of the method. The method applied in previous study, SDA, uses the difference of gross output between two periods for each sector in calculation while simple output multipliers does not. Table 9 describes the summary of the comparison. The next part discusses about the ways in improving Japanese creative industries. 


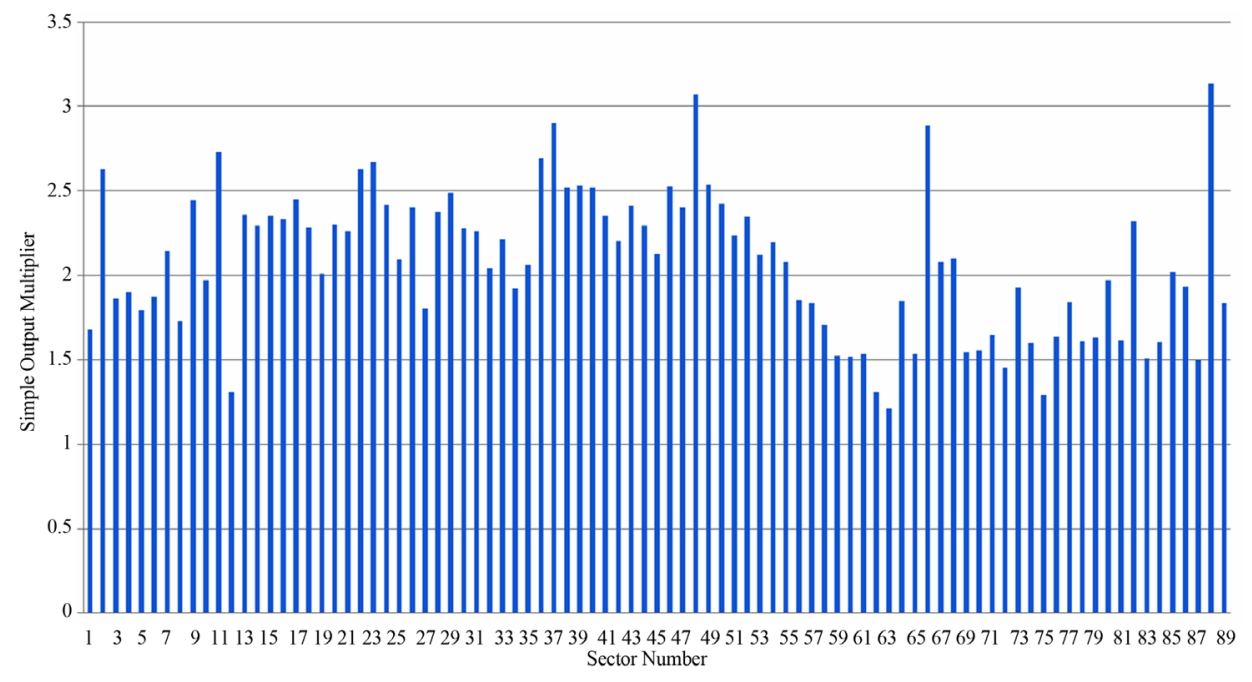

Figure 1. Simple output multiplier of Japanese industrial sectors, 1995. (Source: [10]).

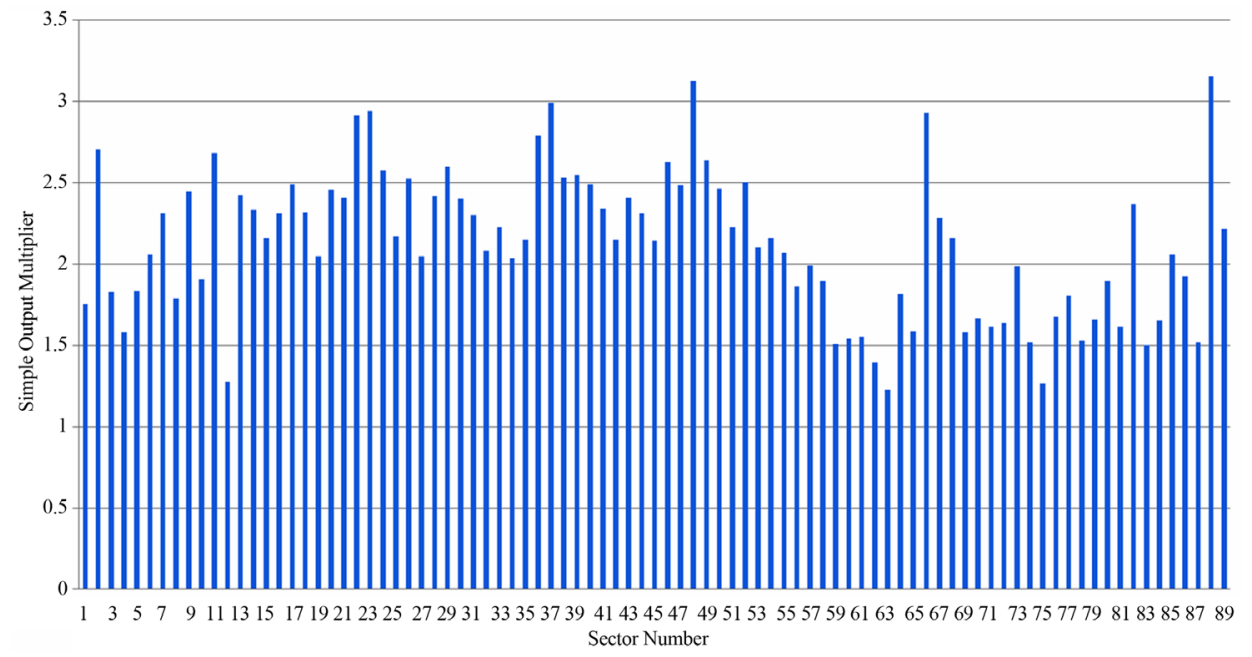

Figure 2. Simple output multiplier of Japanese industrial sectors, 2000. (Source: [10]).

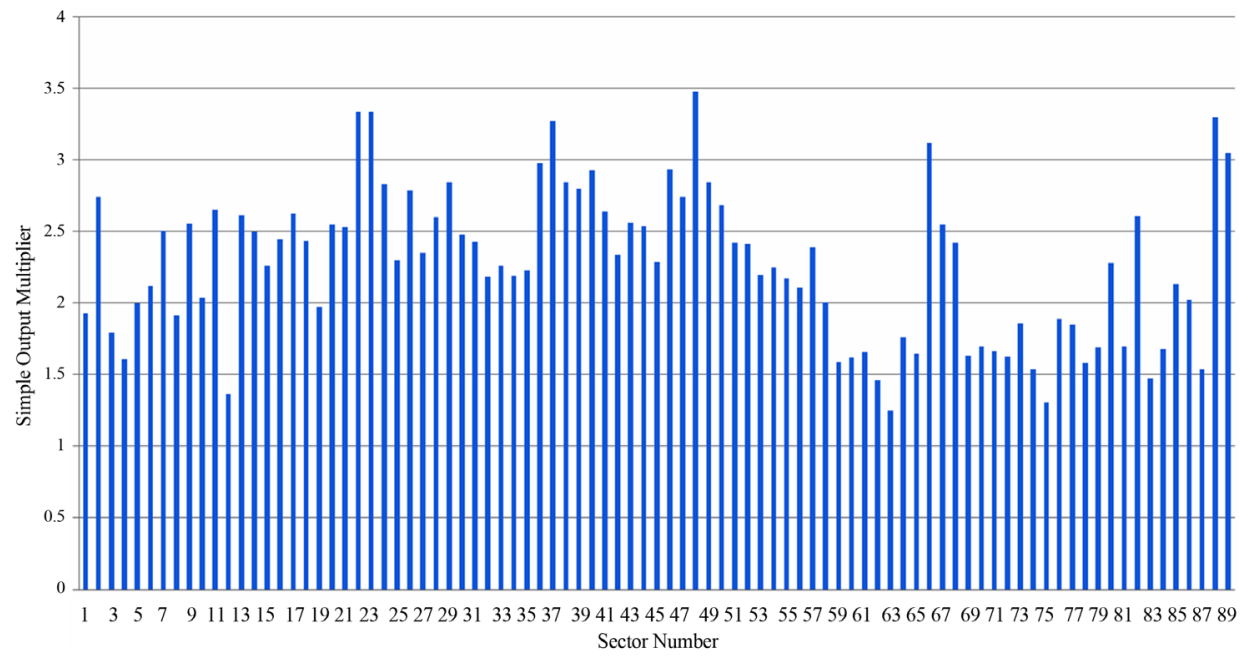

Figure 3. Simple output multiplier of Japanese industrial sectors, 2005. (Source: [10]). 
Table 5. Top five Japanese industrial sectors viewed from simple output multipliers, 1995.

\begin{tabular}{cccc}
\hline No. & Sector Number & Sector Name & Simple Output Multiplier \\
\hline 1 & 88 & Office supplies & 3.14 \\
2 & 48 & Motor vehicles & 3.07 \\
3 & 37 & Steel products & 2.90 \\
4 & 66 & Self-transport by private cars & 2.88 \\
5 & 11 & Feeds and organic fertilizer, n.e.c. & 2.73 \\
\hline
\end{tabular}

(Source: [10]).

Table 6. Top five Japanese industrial sectors viewed from simple output multipliers, 2000.

\begin{tabular}{cccc}
\hline No. & Sector Number & Sector Name & Simple Output Multiplier \\
\hline 1 & 88 & Office supplies & 3.15 \\
2 & 48 & Motor vehicles & 3.12 \\
3 & 37 & Steel products & 2.99 \\
4 & 23 & Synthetic resins & 2.94 \\
5 & 66 & Self-transport by private cars & 2.93 \\
\hline
\end{tabular}

(Source: [10]).

Table 7. Top five Japanese industrial sectors viewed from simple output multipliers, 2005.

\begin{tabular}{cccc}
\hline No. & Sector Number & Sector Name & Simple Output Multiplier \\
\hline 1 & 48 & Motor vehicles & 3.47 \\
2 & 23 & Synthetic resins & 3.34 \\
3 & 22 & Petrochemical basic products and intermediate chemical products & 3.34 \\
4 & 88 & Office supplies & 3.30 \\
5 & 37 & Steel products & 3.27 \\
\hline
\end{tabular}

(Source: [10]).

Table 8. The changes and patterns of simple output multipliers of Japanese creative industries.

\begin{tabular}{|c|c|c|c|c|c|c|}
\hline \multirow{2}{*}{ No. } & \multirow{2}{*}{ Sector Number } & \multirow{2}{*}{ Sector Name } & \multicolumn{3}{|c|}{ Simple Output Multiplier } & \multirow{2}{*}{ Pattern } \\
\hline & & & 1995 & 2000 & 2005 & \\
\hline 1 & 19 & Printing, plate making and book binding & 2.01 & 2.05 & 1.97 & Increasing-decreasing \\
\hline 2 & 47 & Electrical appliance & 2.40 & 2.48 & 2.74 & Increasing \\
\hline 3 & 52 & Miscellaneous manufacturing products & 2.35 & 2.50 & 2.41 & Increasing-decreasing \\
\hline 4 & 76 & Research & 1.64 & 1.67 & 1.89 & Increasing \\
\hline 5 & 81 & Goods rental and leasing services & 1.62 & 1.61 & 1.70 & Decreasing-increasing \\
\hline 6 & 84 & Amusement and recreational services & 1.60 & 1.65 & 1.68 & Increasing \\
\hline 7 & 87 & Other personal services & 1.50 & 1.52 & 1.54 & Increasing \\
\hline
\end{tabular}


Table 9. The summary of the comparison.

\begin{tabular}{cccc}
\hline No. & Attribute & Previous Study & Current Study \\
\hline 1 & Method & SDA & Simple output multipliers \\
2 & The definition of national economy & $\begin{array}{c}\text { National economic } \\
\text { structural changes }\end{array}$ & $\begin{array}{c}\text { The total production made by all industrial } \\
\text { sectors in economy in order to fulfill the increase } \\
\text { of one unit in particular sectors' final demand } \\
3\end{array}$ \\
$\begin{array}{c}\text { The role of Japanese creative industries } \\
\text { in national economy, 1995-2005 }\end{array}$ & $\begin{array}{c}\text { Creative industries had an } \\
\text { important role in 1995-2000 }\end{array}$ & $\begin{array}{c}\text { Creative industries did not have } \\
\text { an important role }\end{array}$ \\
\hline
\end{tabular}

\subsection{Improving the Japanese Creative Industries}

\subsubsection{Printing, Plate Making and Book Binding Sector}

Figure 4 describes the total output of Japanese printing, plate making and book binding sector for each scenario. Based on the information in this figure, Scenario 1, the change of export, has the biggest positive impact to this sector. The positive impact is also generated by Scenario 3, the modification of consumption of outside households. On the other hand, the opposite impact is given by Scenario 2, import modification. These facts indicate that export activity has the biggest potency in increasing the total output of this sector on future period. Therefore, improvements on this activity should be focused.

Export activity, actually, has a close relationship with the term of global competition. In other words, improvements of export activity should consider the competitiveness of sector's output in global market. These improvements need to focus on three aspects, namely 1) quality, 2) price, and 3) marketing of products. These aspects, no matter who is the consumer, will show the strength of products of one sector.

Japanese printing, plate making and book binding companies, as main players in this sector, can improve the quality of this sector's output by tightening the quality control of products. Taking this action will reduce the amount of fail products. Consequently, consumers will difficult to find the defect products in the market. Improvement on price of products, on the other hand, can be conducted by making the process of production more efficient. The example of this action is to choose high ability but cheaper machine for production. This action will reduce the production cost. As a result, the price of product can be reduced without losing the profit. The example of marketing action is to make sure who are and focus on the most potential consumers, especially consumers from abroad.

\subsubsection{Electrical Appliance Sector}

Figure 5 shows the total output of Japanese electrical appliance sector for each scenario. Based on the information in this figure, Scenario 1, the modification of export, has the biggest positive impact to this sector. The positive impact is also generated by Scenario 3, the change of consumption of outside households. The trend of positive impact, however, does not appear in Scenario 2, the import change. In this scenario, total output of this sector on future period decreases. These explanations indicate that export activity should be prioritized in order to increase the total output of this sector.

As discussed in 4.3.1., export activity has a connection with the global competition. The aspects must be focused in order to enhance this activity are quality, price, and marketing of products. The improvement of quality, in the case of this sector, can be done by tightening the philosophy of zero-defect when conducting the production processes. Obviously, the work environment must support the application of this philosophy so it will work effectively. Decreasing of the amount of defect products is a purpose of this application.

On the other hand, the improvement in price aspect can be achieved by carefully choosing the raw materials. The purpose of this action is to reduce the production cost. Besides, employee selection is an important element in pressing the production cost. Selecting high skill but not expensive employee is an actualization of this action. Similar to the previous one, this selection will also reduce the price of product. The example of marketing action is to focus on the most potential consumers, especially consumers from abroad.

\subsubsection{Miscellaneous Manufacturing Products Sector}

Figure 6 describes the total output of miscellaneous manufacturing products sector of Japan for each scenario. This figure shows that the biggest positive impact to this sector is owned by Scenario 1, the export modification. Similar to this scenario, the positive impact is also given by Scenario 3, the change of consumption of outside 


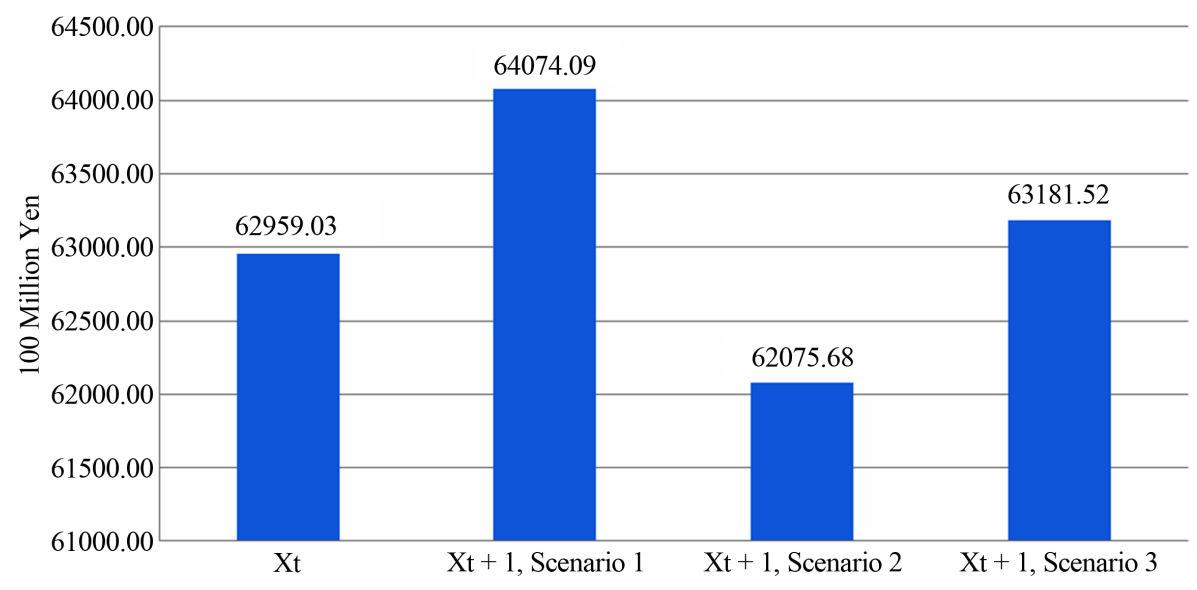

Figure 4. Total output of Japanese printing, plate making and book binding sector for each scenario. (Source: [6]).

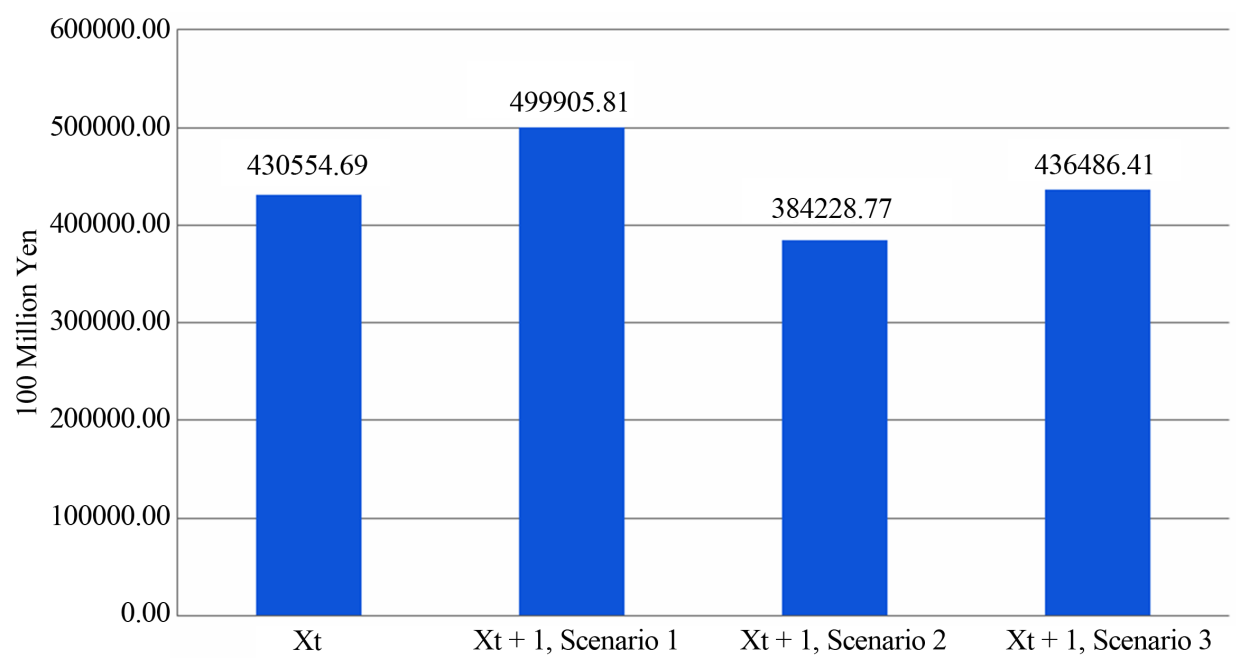

Figure 5. Total output of Japanese electrical appliance sector for each scenario. (Source: [6]).

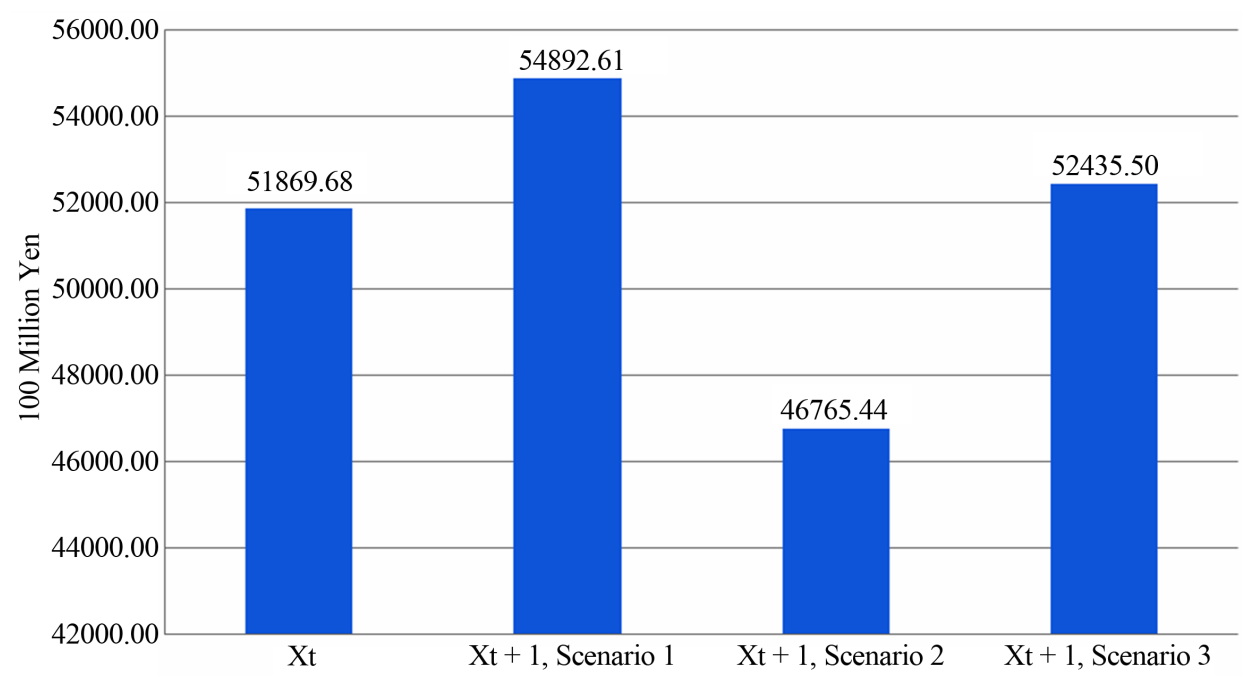

Figure 6. Total output of Japanese miscellaneous manufacturing products sector for each scenario. (Source: [6]). 
households. Meanwhile, the negative impact is generated by Scenario 2, the change of import. Therefore, activity of export is the most potential thing in increasing the total output of this sector.

Similar to the discussions on previous sectors, the aspects must be considered in improving export activity are quality, price, and marketing of products. In this sector, the analysis related to the improvement on these aspects will focus on subsector of toys and games. The example of action in improving quality aspect is to know the definition of the defects of product. Another example of this action is to know how to prevent these defects. One of the prevent acts is to provide space allowance among products so the frictions, especially when grabbing one of these, can be avoided.

The price improvement, similar to the discussions on previous sectors, can be achieved by making the processes of production more efficient. In this subsector, choosing the high level but cheaper software is an example of this improvement. Besides, the selection of components of toys is also important thing in this improvement. Obviously, high quality but cheaper components are main target in this action. The production cost reduction and decreasing of production price are main targets of this improvement.

On the other hand, improvement action related to the marketing aspect is to know the most potential consumers for particular product. For example, the role playing games are suitable for teenage consumers. They like this genre because the level of difficulty is not so high. Besides, they also like the romance games. Meanwhile, the adventure games are suitable for children. This genre is fun and easy. Contrarily, the games which the difficulty is high will match with adult consumers. The examples of these games are strategic and simulation. The sport games (e.g. football and basketball) are different because it can be enjoyed by all consumers. Based on these explanations, knowing the suitable consumers for one product, especially consumers from abroad, will improve the activity of export.

\subsubsection{Research Sector}

Figure 7 describes the total output of research sector of Japan for each scenario. Based on the information in this figure, the biggest positive impact to this sector is generated by Scenario 1, the export modification. Positive impact is also owned by Scenario 3, the change of consumption of outside households. Contrarily, the negative impact is generated by Scenario 2, the import modification. Therefore, export activity must be focused in order to increase the total output of this sector.

This sector is chosen because it has research institutes for cultural and social science as a subsector. The analysis of this sector will focus on these institutes. More specifically, the analysis of this sector is focused on export activity of the institutes.

Usually, export activity has a similar meaning with the selling of products of one sector to abroad. For this sector, the product is a right of patent. The example of this right is a method in creating the creative products which the original culture of Japan is embedded. Based on these explanations, the way in enhancing the total output of this sector through export activity is to increase the level of selling of the right to foreign companies or organizations.

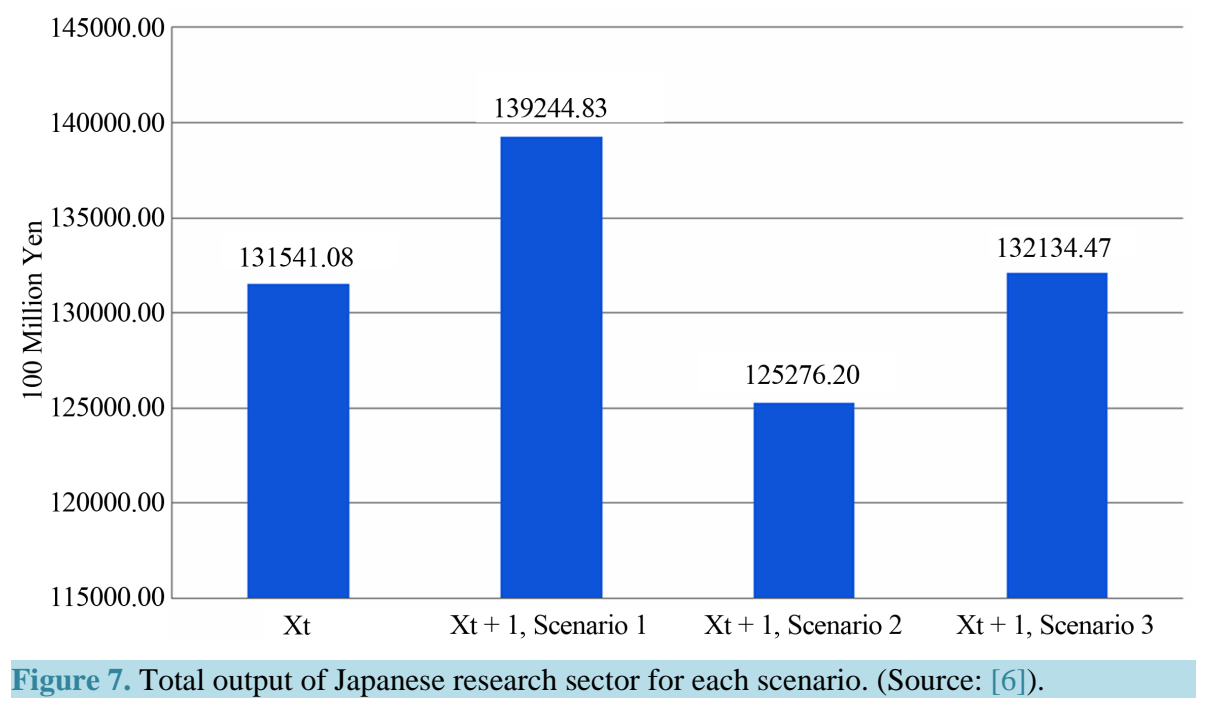




\subsubsection{Goods Rental and Leasing Services Sector}

Figure 8 shows the total output of Japanese goods rental and leasing services sector for each scenario. This figure explains that Scenario 1, the export change, has the biggest positive impact to the total output of this sector. Another positive impact is owned by Scenario 3, the modification of consumption of outside households. The impact of this scenario, however, is less than Scenario 1. Meanwhile, opposite impact is generated by Scenario 2, the import change. Therefore, the analysis related to this sector will focus on its export activity.

As mentioned in previous discussions, quality, price, and marketing of products are the critical aspects in export activity. This philosophy is also suitable for this sector. The quality of products of this sector can be maintained by doing the well maintenance and reparation actions while improvement in prices of products can be reached by reducing the costs of maintenance and reparation processes. Reference [11] argued that maintenance cost of industrial plants of Thailand can be reduced through increasing predictive maintenance and reducing preventive maintenance. Therefore, using this concept, the reduction of prices of products in this sector can be achieved by implementing predictive maintenance. The improvement on marketing aspect, on the other hand, can be accomplished by providing more employees who can speak English fluently. This action will distribute more information related to the sector's products to foreign consumers.

\subsubsection{Amusement and Recreational Services Sector}

Figure 9 shows the total output of amusement and recreational services sector of Japan for each scenario. This figure explains that Scenario 3, the change of consumption of outside households, has the biggest positive impact to this sector. The positive impact is also owned by Scenario 1, the modification of export. The impact of this scenario, however, is less than Scenario 3. On the other hand, the opposite impact appears in Scenario 2, the change of import. Therefore, the efforts in increasing the total output of this sector must be focused on above consumption.

The example of above effort is to decrease the entry fee, including the fee on weekend and holidays, of amusement and recreational places, such as movie theaters. This action will enhance the interest of consumers, especially consumers of outside households, so they will come frequently to these places. Another example is to add the attractions which the format is based on the request from these consumers. This effort is also a sign of appreciation for them. The profit of above places, using these actions, might increase because consumers will be more satisfied.

\subsubsection{Other Personal Services Sector}

Figure 10 describes the total output of Japanese other personal services sector for each scenario. Based on the information in this figure, the biggest positive impact to this sector is owned by Scenario 3, the modification of

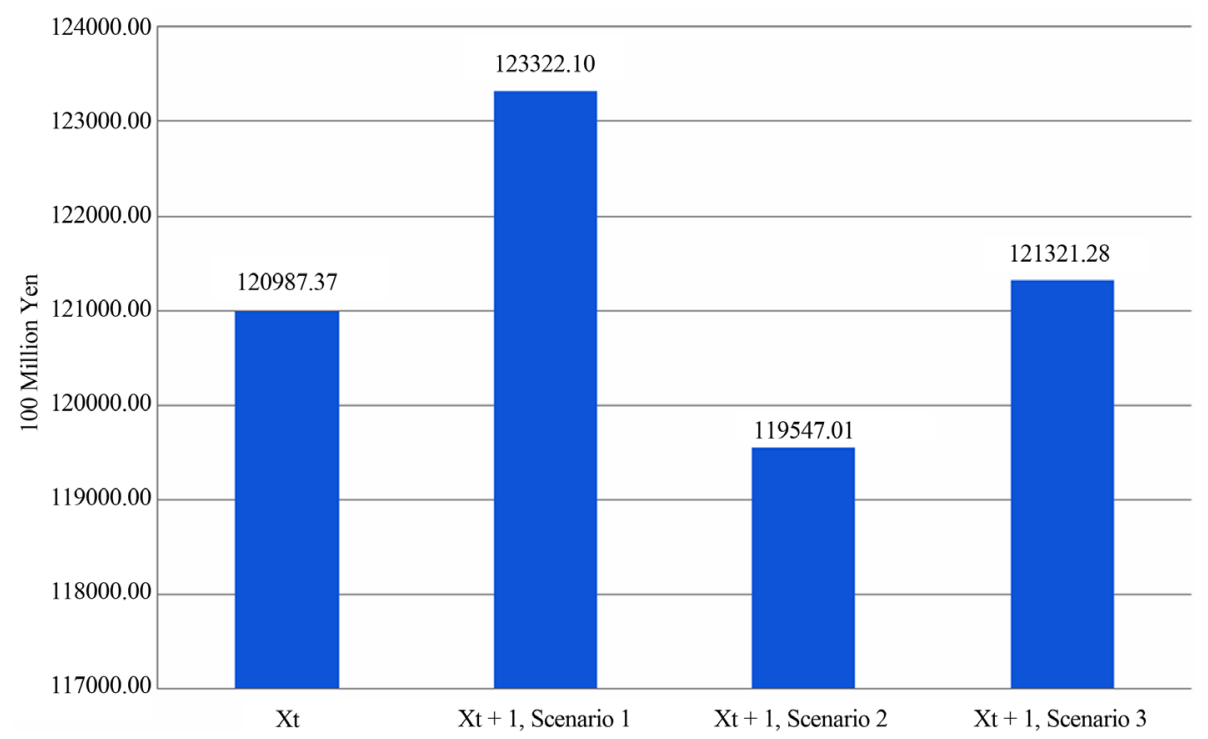

Figure 8. Total output of Japanese goods rental and leasing services sector for each scenario. (Source: [6]). 


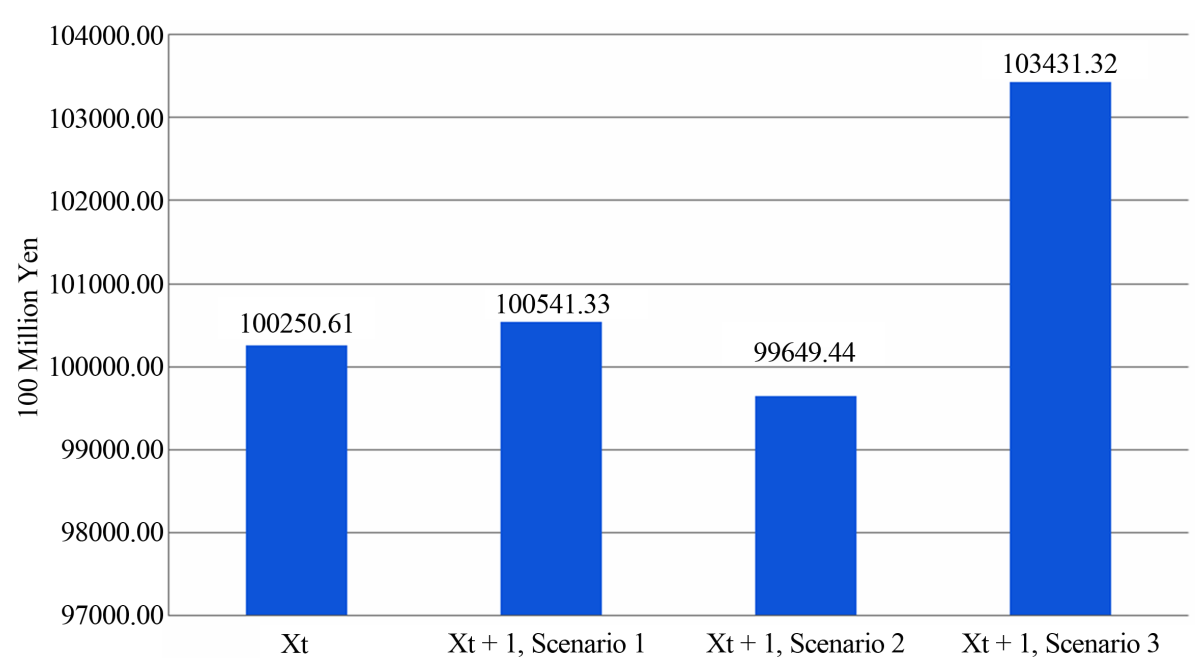

Figure 9. Total output of Japanese amusement and recreational services sector for each scenario. (Source: [6]).

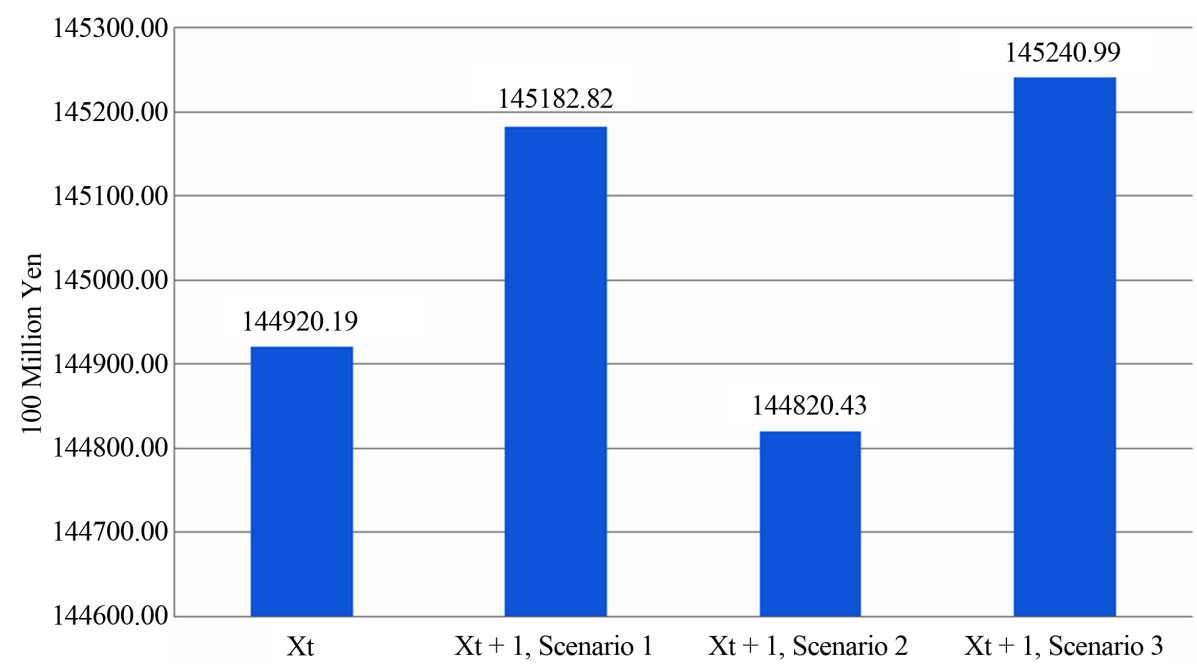

Figure 10. Total output of Japanese other personal services sector for each scenario. (Source: [6]).

consumption of outside households. Scenario 1, the modification of export, also has positive impact but it is less than Scenario 3. Conversely, the negative impact is generated by Scenario 2, the import change. Therefore, the improvement efforts in enhancing the total output of this sector must be focused on above consumption.

The example of output of this sector is an instruction service for the activities of arts and cultural. Decreasing the fee of this service is one of the attempts in increasing the interest of consumers of outside households. Besides, giving the free trial in doing arts activities will also attract their attention in trying these. As a result, the profit of this sector might increase because many consumers interested in the sector's services.

Previous analysis shows that the patterns of total outputs of creative industries of Japan on future period are different. Nevertheless, these sectors have one similarity, namely Scenario 2, the change of import, will decrease their total output. This phenomenon explains that import restriction related to these sector's products is needed.

\section{Conclusions and Further Research}

This study had two purposes, namely 1) to get another perspective related to the role of creative industries in national economy of Japan from 1995-2005 and 2) to know the ways to improve these sectors. Comparison with previous study was conducted in order to achieve the first objective. Previous study, using SDA, showed that 
creative industries had an important role in national economy of Japan in 1995-2000 while the opposite phenomenon could be observed in 2000-2005. Another perspective related to above role was obtained from this study, namely creative industries, using simple output multipliers method, did not have an important role in national economy of Japan in analysis period.

The results also showed that the patterns of total output of creative industries of Japan on future period were not identic. Nevertheless, these sectors had one similarity, namely Scenario 2, the modification of import, will decrease their total output. This phenomenon indicated that import restriction related to these sector's products was needed.

This study, however, only analyzed the impact of final demand changes on total output of Japanese creative industries. In other words, deeper analyses on other points, such as statistical analysis of influences of Japanese creative industries in national economy and analysis of Japanese policies related to these sectors, were not discussed in this study. These analyses are also important and must be considered in order to improve above industries. Therefore, this study suggests above deeper analyses as further researches. Another suggested further research from this study is an international comparison, especially the comparison between developed and developing countries, related to this topic. This comparison will show the difference of the characteristics of creative industries in analyzed countries, especially when final demand changes happened.

\section{Acknowledgements}

This paper is a revised and expanded version of a paper entitled "Analyzing the Dynamics of Total Output of Japanese Creative Industry Sectors: An Input-Output Approach” presented at International Conference on Applied Economics (ICOAE2013), Istanbul, 27-29 June, 2013.

\section{References}

[1] United Nations Conference on Trade and Development (UNCTAD) (2004) Creative Industries and Development. São Paulo, 13-18 June 2004. http://unctad.org/en/docs/tdxibpd13_en.pdf

[2] Wong, C.Y. and Gao, R. (2008) Creative Industry in UK, Japan and China: A Supply Chain Management Perspective. http://www.b.kobe-u.ac.jp/paper/2008_01.pdf

[3] Booyens, I. (2012) Creative Industries, Inequality and Social Development: Developments, Impacts and Challenges in Cape Town. Urban Forum, 23, 43-60.

[4] Zuhdi, U. and Putranto, N.A.R. (2012) Examining the Role of Creative Industry Sectors in National Economic Structural Changes of Japan. Proceedings of 19th International Business Research Conference 2012, Melbourne, 19-21 November 2012, 1-11.

[5] Zuhdi, U. (2012) Analyzing the Influence of Creative Industry Sector to the National Economic Structural Changes by Decomposition Analysis: The Case of Indonesia. Procedia-Social and Behavioral Sciences, 65, 980-985. http://dx.doi.org/10.1016/j.sbspro.2012.11.230

[6] Zuhdi, U., Prasetyo, A.D. and Sianipar, C.P.M. (2013) Analyzing the Dynamics of Total Output of Japanese Creative Industry Sectors: An Input-Output Approach. Procedia Economics and Finance, 5, 827-835. http://dx.doi.org/10.1016/S2212-5671(13)00095-6

[7] UK Department for Culture, Media and Sport (DCMS) (1998) Creative Industries Mapping Document, 1998. http://www.creativitycultureeducation.org/creative-industries-mapping-document-1998

[8] Nippon Life Insurance (NLI) Research (2009) Creative Industry Trends-The Creative-Industry Profiles of Japan's Ordinance-Designated Cities. http://www.nli-research.co.jp/english/socioeconomics/2009/li091015.pdf

[9] Miller, R.E. and Blair, P.D. (2009) Input-Output Analysis: Foundations and Extensions. 2nd Edition, Cambridge University Press, New York. http://dx.doi.org/10.1017/CBO9780511626982

[10] Zuhdi, U. (2014) The Other Perspective Related to the Role of Information and Communication Technologies Sectors in National Economy: The Case of Japan. Advanced Science Letters, 20, 483-486. http://dx.doi.org/10.1166/asl.2014.5334

[11] Chumai, R. (2009) System Dynamic Modeling of Plant Maintenance Strategy in Thailand. Proceedings of the 27th International Conference of the System Dynamics Society, Albuquerque, 26-30 July 2009, 1-16. 


\section{Appendix}

Japanese industrial sectors.

No. Sector Name

1 Crop cultivation

2 Livestock

3 Agricultural services

$4 \quad$ Forestry

$5 \quad$ Fisheries

$6 \quad$ Metallic ores

$7 \quad$ Non-metallic ores

8 Coal mining, crude petroleum and natural gas

$9 \quad$ Foods

10 Beverage

11 Feeds and organic fertilizer, n.e.c.

12 Tobacco

13 Textile products

14 Wearing apparel and other textile products

15 Timber and wooden products

$16 \quad$ Furniture and fixtures

17 Pulp, paper, paperboard, building paper

18 Paper products

19 Printing, plate making and book binding

20 Chemical fertilizer

21 Industrial inorganic chemicals

22 Petrochemical basic products and intermediate chemical products

23 Synthetic resins

24 Synthetic fibers

25 Medicaments

26 Final chemical products, n.e.c.

$27 \quad$ Petroleum refinery products

28 Coal products

29 Plastic products

30 Rubber products

31 Leather, fur skins and miscellaneous leather products

32 Glass and glass products

33 Cement and cement products

34 Pottery, china and earthenware 


\section{Continued}

Other ceramic, stone and clay products

Pig iron and crude steel

Steel products

Steel castings and forgings and other steel products

Non-ferrous metals

Non-ferrous metal products

Metal products for construction and architecture

Other metal products

General industrial machinery

Special industrial machinery

Other general machines

Machinery for office and service industry

Electrical appliance

Motor vehicles

Ships and repair of ships

Other transportation equipment and repair of transportation equipment

Precision instruments

Miscellaneous manufacturing products

Building construction

Repair of construction

Civil engineering

Electricity

Gas and heat supply

Water supply

Waste management service

Commerce

Finance and insurance

Real estate agencies and rental services

House rent

Railway transport

Road transport (except transport by private cars)

Self-transport by private cars

Water transport

Air transport

Freight forwarding

Storage facility service 


\section{Continued}

\begin{tabular}{ll}
\hline 71 & Services relating to transport \\
72 & Communication \\
73 & Broadcasting and information services \\
74 & Public administration \\
75 & Education \\
76 & Research \\
77 & Medical service and health \\
78 & Social security \\
79 & Other public services \\
80 & Advertising, survey and information services \\
81 & Goods rental and leasing services \\
82 & Repair of motor vehicles and machine \\
83 & Other business services \\
84 & Amusement and recreational services \\
85 & Eating and drinking places \\
86 & Accommodations \\
87 & Other personal services \\
88 & Office supplies \\
89 & Activities not elsewhere classified \\
\hline
\end{tabular}

